\title{
FACILITATING AFFORDABLE HOUSING IN THE UK MARKET THROUGH SOCIALLY-ORIENTED ISLAMIC FINANCIAL INSTITUTIONS
}

\author{
Yusuf Jha*
}

\begin{abstract}
In the context of the growing global shortage of affordable housing, policy discourse in the last decade has centred on ways to get the private sector involved through a variety of public-private partnerships. This paper focusses on two such contemporary applications of community centred alternatives in Community Land Trusts (CLTs) and Shared Ownership Co-operatives (SOCs) and explores ways in which mainstream Islamic Finance can engage and support them. By focusing on the "private funding gap" that exists between mainstream finance and these community centered programs, the paper posits that Islamic Finance Institutions (IFIs) are well placed to provision financial support to such initiatives through the effective use of cash based endowments or awqaf. Such a re-structuring process within Islamic Finance proposes not only to allow IFIs effectively to assist in providing affordable housing but also promises to enable them to fulfil their originally stated socio-economic ideals better.
\end{abstract}

"In the empires of usury the sentimentality of the man with the soft heart calls to us because it speaks of what has been lost."

- Lewis Hyde

\section{Introduction}

The unaffordability of property today is a global problem. In the UK specifically, the average price of a home has risen by over 43 times since 1971, increasing from $£ 5,632$ to $£ 245,319$ (Shelter, 2013). For the past decade this has meant areas in London, for example, have had house prices appreciate at an annual rate higher than the salary of the capital's key workers, heralding the contemporary phenomenon of "houses earning more than people" (New Economics Foundation, 2003).

Whilst various causes have been identified for such price inflation, the magnitude and complexity of the problem indicates that governments and markets alone are unlikely to provide a solution. This has led to an increasing recognition of a need for the 'third sector', (consisting of community driven organisations) to contribute to economic development (Salomon and Anheier, 1997). Two such 'third sector' models in the form of Community Land Trusts (CLTs) and Shared Ownership Co-operatives (SOCs) have been arguably said to be amongst the most effective contemporary tools in both tackling property inflation and providing long-term affordability (Davis, 2006). Despite this, 
they have received little support and recognition from mainstream commercial finance, Islamic finance included.

Whilst Muslim societies have historically been founded on a similar third sector, public-private partnerships in the form of trusts or civic endowments for public welfare (lit. awqaf), the challenge remains for the contemporary Islamic Finance sector to revive such a dynamic. This paper explores avenues for such a revival by examining the potential of coupling Islamic Finance Institutions (IFIs) and awqaf with a view to provisioning financial support for community endeavours such as CLTs and SOCs.

\section{Causes of Property Price Inflation}

Neoclassical economic literature concerning house prices contends that prices are determined by free market forces of supply and demand wherein the "equilibrium" price is when these two forces equalise (Landsburg, 2002). Within this dynamic, economists tend to explain the inflation of property prices as that of supply decreasing and demand increasing. Some of the factors that may contribute to such a scenario include a decrease in housing stock, an increase in population growth and a receding land supply. Within a UK specific context, all three factors have been highlighted as the main contributors to property inflation by the official government Barker Report (2003) on affordable housing. This report identified the main constraint on property prices as being limited land supply, citing regulatory relationship and control over the use of land as influencing the way in which such land is used for development.

Despite perspectives such as the Barker Report dominating mainstream discourse, recent times have seen increasing advocacy of an alternative view. In contradistinction to neoclassical economics, voices such as Keen (2011), Werner (2010), Douthwaite (2000), Diwany (2003), Kennedy (2012) and the monetary reformist group Positive Money (2013:1) all state that the inflation of property prices is not so much an economic issue of supply and demand as of being one of monetary policy, wherein the main issue is the role of bank credit in the nation's money supply. It is the process of money creation that Keen (2011) and Werner (2010) contend has led to speculative lending and contributed to the price inflation of property. They posit that as money is created, "in amounts exceeding the ability of the economy to create new goods and services, the result is inflation (Eisenstein, 2007, p. 269)". Furthermore Voith and Wachter (2012) contend that such inflation particularly impacts land in demonstrating that land prices for well-located, desirable communities increases faster than wages in low- and moderate-wage occupations.

Empirical support in favor of the view that money creation is linked to property price inflation may be seen in the positive correlation between bank lending in the 
UK and in domestic property price appreciation for the same period. As Figure 1 shows below, by focusing on UK house prices over an extended period (19972010), the increase in Population and Housing Stock remains fairly constant, whilst it is the fluctuation in bank lending (conventional mortgages) that displays a positive correlation with the corresponding increase in house prices.

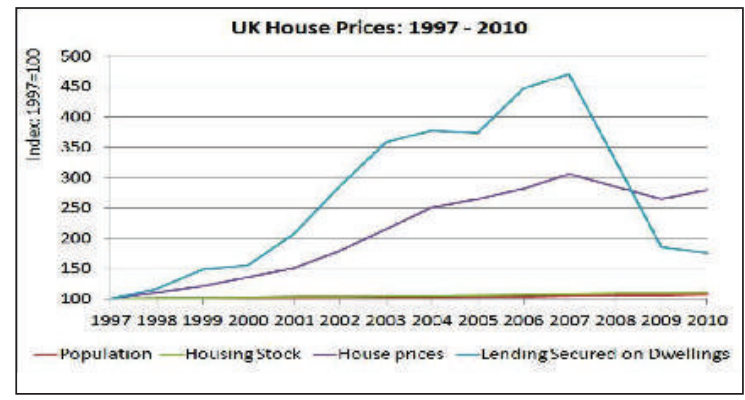

(Source: Positivmoney.org)

\section{Figure 1 Fluctuation of UK house prices over 1997-2010}

The argument of bank lending being the primary cause of property price appreciation is further supported in Figure 2, wherein the change in UK house prices and that of the adjusted net change in lending over the same period appear to be so synchronised, as to be unable to be explained by other causal factors.

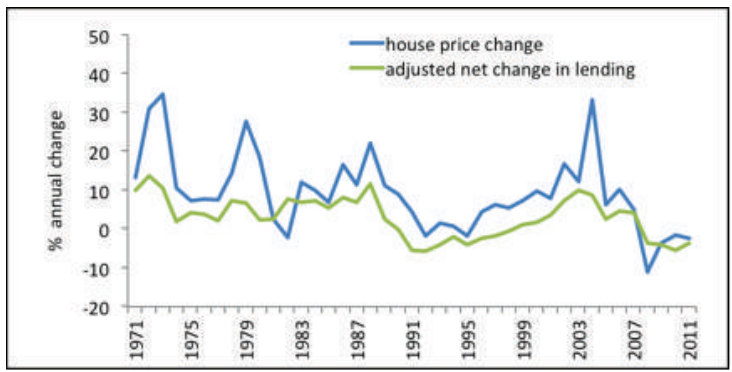

(Source: Positivmoney.org)

\section{Figure 2 Fluctuation in UK house prices and lending (\% annual change)}

The patterns in house prices indicated through both Figure 1 and Figure 2 point to a direct, positive correlation with the amount of money lent into the economy. This is important because if bank lending towards property acquisition is itself understood to be the primary contributory towards property price inflation, 
then the role of community inspired initiatives outside of the banking network acquire increasing import, especially if this inflation is intended to be countered. This is where the two key models of Community Land Trusts (CLTs) and Shared Ownership Co-operative models (S0Cs) particularly stand out, as an analysis of both models illustrates.

\section{Community Land Trusts (CLTS)}

A Community Land Trust (CLT) operates by extracting land from the market and retaining it as a public asset under the community ownership of a non-profit seeking Trust. With land costs becoming an increasingly significant part of house prices (often $40-60 \%$ of the final price), such removal of land from the market allows for property affordability to be preserved on a long-term basis for future generations (NEF, 2003).

\section{CLTs: History, Motivation and Techniques}

The CLT model was originated in the United States by Ralph Borsodi, Slater King and Robert Swann, drawing upon earlier examples of planned communities intended to steward affordable housing on leased land (Davis, 2010, p.3-48). Their early inspirations include the Garden city movement in the United Kingdom, Single Land Tax communities in the USA (based on the ideas of the late economist Henry George) and Ghandian inspired Gramdan villages in India, such as the Land Gift movement of Vinoba Bhave (Davis, 2010, p.108-113).

From the beginning CLTs were premised on servicing the needs of communitybased individuals in providing access to land and maintaining security of tenure with regards to property affordability, economic diversity and local services. In that regard they exhibit behaviour similar in nature to land based awqaf that existed throughout the Muslim world. Though there is significant variation among the hundreds of CLTs in the globe today (thereby indicating their flexibility), some common key features to be found amongst them include:

1. Nonprofit Corporation - A community land trust is an independent, notfor-profit Corporation that is legally chartered in the state in which it is located (Davis, 2010, p.113).

2. Dual Ownership - A nonprofit corporation (the CLT) acquires multiple parcels of land throughout a targeted geographic area with the intention of retaining ownership of these parcels perpetually (Davis, 2010, p. 221).

3. Leased Land - CLT acquired land is treated as a common heritage, not as an individual possession. While CLTs remove their land permanently from 
the market, intending never to resell, they can provide for the exclusive use of their land through its conveyance to individual homeowners (or to the owners of other types of residential or commercial structures) through long-term ground leases (Davis, 2010, pp. 221-228).

4. Perpetual Affordability - CLTs typically retain a repurchase option for any residential (or commercial) structures located upon its land. The resale price is set by a formula designed to ensure a modicum between being a fair return on investment as well as giving future homebuyers affordable access to housing (Davis, 2006).

5. Perpetual Responsibility - With CLTs being integral owners of land through any ground lease structures and having first option of repurchase, their interest to ensure responsible use of premises and property is lockedin perpetually and unlike conventional property developers does not disappear once a building is sold (Davis, 2010, pp. 221-228).

6. Community Based - Typically CLTs operate within the physical boundaries of a targeted locality, being guided and accountable to the people who encompass the respective community (Davis, 2010, pp. 221228).

7. Representative Governance - Management structures such as Board of Directors in CLTs typically seek tripartite democratic governance structures; representing proportional interests of community leaseholder residents, adjoining community (non-residents) and public governance bodies (Davis, 2010, p. 402).

\section{CLTs: Case Studies and Proof of Concept}

In a recent publication commissioned by the University of Salford (Paterson \& Dayson, 2011), more than ten CLTs in the UK were demonstrated to have exhibited 'proof of concept', in their facilitation of 'the completion of 137 homes, with a further 92 on site, alongside other projects in the pipeline" (Paterson \& Dayson, 2011, p. 17). Whilst the majority of CLTs in the UK have been on rural sites, recent times have also seen the emergence of urban CLTs in the form of the Cashes Green Community Land Trust (based in Gloucestershire, seeking to build 78 homes on a derelict hospital site) and the East London Community Land Trust seeking development and stewardship of a local hospital alongside small developments for local residents within the Olympic Park legacy neighborhoods of East London. 


\section{Shared Ownership Co-operatives (SOCs)}

Shared Ownership Co-operative (SOC) housing operates on a part buy/part rent basis and seeks to provide a "third way" of land tenure between home ownership and renting, allowing residents to pay an affordable rent on the share of equity they do not own. This is similar to the commonly called Diminishing Musharaka arrangement in Islamic Finance, albeit the pricing arrangements in SOCs are typically more equitable than those of commercial "Islamic" banks, as they do not involve benchmarks to pre-agreed interbank lending rates. Generally speaking, SOCs have three distinguishing features: the owner-occupancy of residential property; the fair allocation of equity between lower-income homeowners and future owners; and the sharing of rights, responsibilities, and benefits of residential property between individual homeowners and the other controlling party (Davis, 2006 and 2008).

\section{SOCs: History, Motivation and Techniques}

Research shows that SOCs as a form of limited-equity mutual housing were popular in Britain in the past, especially prior to the First World War and in the 1960s and 1970s when they were developed for what were then key workers (NEF, 2003). Such models were actively championed by various socially conscious economists in the late 1970s-early 1980s, typically pairing a lower income household wanting to buy a home with a local shared equity program that would co-invest in the equity of the property by contributing to the relevant unaffordable portion of their mortgage. The homebuyer would then build equity each month as they paid off their mortgage, with any price appreciation on the property being limited in order to preserve affordability for any other future low income buyer (Davis, 2006).

As SOCs involve a shared commitment to balancing the twin goals of preserving housing affordability for future generations alongside offering homeowners a dependable opportunity to build wealth; they are mostly managed by public or nonprofit agencies that share some of the rights, responsibilities, risks and rewards of ownership (Davis, 2006). Some of the key features of SOCs include:

i. Security of Home Ownership: By virtue of the buyer's share in the home's equity (e.g. $20 \%$ shares), their lease on the home is secured. With the purchase of more shares, the rent on the outstanding portion will be reduced pro rata (Carswell, 2012 and Davis, 2008).

ii. No Default Risk: As the core relationship of SOCs is that of ownership/ partnership rather than lender/borrower, it is impossible for the prospective buyer to "default" on "loan repayments", since the financing is not debtbased but rather equity-based and as such, $a b$ initio, there is no "loan" to 
"default" on (Davis, 2008).

iii. Community Based Cooperatives: Though not necessarily non-profit, the cooperatives typically managing such schemes should represent the interests of the wider community within the area, being primarily concerned with the fair allocation of equity and sharing of rights, responsibilities, and benefits of residential property accruing to the individual homeowners and the community as a whole (Carswell, 2012).

iv. Fair Allocation of Equity: All SOC models place an emphasis on the fair allocation of equity, focusing specifically on how the appreciating value of residential property is rightfully apportioned between the homeowners and the community. Thus SOCs seek to balance the creation of private wealth against the retention of public wealth through contractual controls such as resale price caps ${ }^{1}$ (Davis, 2006 and 2008).

\section{SOCs: Case Studies and Proof of Concept}

The concept of SOCs does not represent something new in a UK context, being similar to "non-equity co-ops set up in the 1980s under the Housing Corporation in England and Wales, and even more similar to the community ownership co-ops set up in Scotland to take over public housing estates" (NEF, 2003, p. 24). The decline of such models in their historical UK context was that with increasing privatisation under the conservative Government, the models had no design features to prevent demutualisation and the schemes were inevitably sold onto the open market to property developers keen to pay above their book value. Interestingly, "Between 1961 and 1977 across the UK 1,222 co-ownership societies were formed, producing over 40,000 units. However following the 1980 Housing Act most societies decided to dissolve and sell to their members, leaving only 31 co-ownership societies today registered with the Housing Corporation" (GLA, 2004, p. 14).

However, it is worth noting that those SOC schemes which did provide for a degree of equity lock, "that combined the benefits of renting and owner-occupation in the form of shared ownership co-operatives (GLA, 2004, p. 14)" were able to continue to work successfully. Examples include the East London based Glenkerry House, ${ }^{2}$ which has been operative for the past 24 years in running a 14-storey tower block as a community leasehold co-op, with the local London Borough as the freeholder. As a report for the London Mayor highlights, Glenkerry House represents "an ideal case study when developing a new model of shared-equity co-operative housing" (GLA, 2004, p. 24). 


\section{The Model of Combining SOCs and CLTs}

The potential to combine successful design features of SOCs such as Glenkerry House with that of CLTs has been actively explored in recent times and proposed as a viable solution to the current crisis of affordable housing. Research (Miriam, John and Harold, 2012) and proposals from leading think tanks (NEF, 2003) have sought to detail CLT and SOC combination structures, thereby effectively creating a model of resale-restricted, owner-occupied housing that aims structurally to tackle property inflation as well as provide long-term affordability to its residents (Davis, 2006).

The potential synergy between both structures, with one focused on the land and the other on the development of property upon the land has been found not to only preserve affordability but also to build social capital (through the nurturing of social networks) and civic engagement (through wider involvement in the civic associations of the local community). Studies in low-income housing projects with a troubled history of deferred maintenance, criminality, and general distress have shown that the vehicle of such shared ownership builds collective responsibility and spurs collective action, thus improving conditions for all residents (Davis, 2006).

A combination of both structures would typically involve:

i. Purchase of Land by CLT: With a one-time purchase of a land plot/ land parcels required by the CLT, in the absence of the land being gifted to the CLT, this step would represent a significant financial hurdle (and accordingly an opportunity for socially orientated financial institutions). Either way, this step is essential as it allows the land to be permanently taken off the speculative market thus preserving its affordability (Davis, 2010).

ii. Development/Purchase of Property by SOC Cooperatives: typically involving leasing land from the CLT under a 99-year ground lease, any number of separate co-operative housing societies may partner with the CLT to develop, own and manage multi-unit residential buildings. The SOCs would then further allow for buyers/homeowners to gradually build up ownership of buildings, as opposed to the land which remains with the CLT (Davis, 2006).

The many benefits of such a structure to residents would include secure tenure of residence as well as affordable and equitable housing payments. Benefits to future residents would likewise be preserved through a clear and transparent resale formula that locks in permanent affordability for generations to come of low to moderate income households (Davis, 2006, 2008 and 2010). 


\section{The "Funding Gap" Opportunity for IFIs}

The Financing requirements for both CLTs and SOCs would not differ in principle from that required by any other non-profit developer of affordable housing. Funds would thus be needed (either as equity or debt), inter alia, to pay for two broadly classified categories of pre-development finance (e.g. site surveys, architect costs, planning permission fees and land acquisition) and development finance (e.g. construction/purchase of residential/commercial structures).

Currently most funding for joint CLT-SOC structures comes from government grants for both land acquisition and project development, with sustainable operational funding generally coming via partnership contracts with housing associations, socially orientated venture capital funds and in some cases from community driven investment funds such as the Community Land Trust Fund ${ }^{3}$ in the UK.

Despite this, there still exists a significant "funding gap" at the private commercial financial institutional level (Community Finance Solutions, 2009). Interestingly, in the UK, only the Charity Bank and Troidos Bank have been explicitly noted to support financially the provision of CLT and SOC projects (Troidos Bank, 2013) - no IFIs state the same. This general lack of mainstream commercial funding for affordable housing, inclusive of the lack of support from mainstream Islamic Financial Institutions (IFI), may be attributable to the following:

1. Lack of willingness to take on the development risk;

2. Tendency of such institutions to provide debt financing in a manner inevitably pegged to a fixed or inflation linked interest payment; and

3. The credit/risk departments in such institutions being totally unfamiliar with the nature of the asset class.

In light of the above and the corresponding neglect by conventional financial institutions, potential exists whereby CLT and SOC projects could be actively supported by mainstream IFIs. This "funding gap" promises not only to provide further diversification opportunities for IFIs themselves, but also to enable a greater realisation of their socio-moral ethics, something which has been found questionable by both academics and laymen alike.

\section{IFls and Social Responsibility: The Forgotten Obligation}

Pioneering Islamic economists (Baqir al-Sadr, 1968; Mawdudi, 1969; Chapra, 1970 and Kahf, 1973) sought to place the Islamic Economic system as one that would promote universal brotherhood, provide for a more equitable modality of distribution of income and allow for individual financial freedom through the fulfilment of basic human and spiritual needs. Such early ideals were to be translated into practise 
wherein scholars such as Asutay (2008) note that the initial experience of Islamic Finance "in Egypt in late 1960s was structured as a socially-oriented institution, aimed to provide credit to peasants, small businesses, and workers to overcome financial exclusion and expand the ownership base of society."

It was the transformation of Islamic Finance into its current commercial banking form, heralded by the arrival of the first Islamic commercial Bank (Dubai Islamic Bank) in 1975 that led to a marked change in direction. This is best evidenced by the subsequent reliance in Islamic Banks on the Murabaha contract, being "essentially a form of deferred payment sale, described as "interest-like" owing to its implied acceptance of the time value of money" and said to contribute to nearly $70 \%$ of all financing in Islamic Banks thereafter (Delorenzo, 1999). Since then, in keeping with the profit maximisation of limited liability corporations, successful financial performance has held priority "at the expense of the "social and economic developmentalist' aspirations of Islamic moral economy” (Asutay, 2012). This has meant that whilst the Islamic Finance industry has performed well in financial terms, having grown in size from around US\$10 billion of total invested assets in 1975 to just over US\$1.8 trillion in 2013 (Ernst and Young, 2013), its performance in terms of earlier advocated socio-ethical goals has been arguably less commendable (Asutay 2007, 2008 and 2012).

\section{Debating the Ethical Practice of IFIs}

The trajectory of mainstream IFIs from 1975 onwards has understandably been akin to that of commercial banks and financial institutions. As Ahmed (2010) notes, this can be demonstrably shown to be that of:

i. Mirroring conventional finance through an adoption of fixed return instruments benchmarked to interest rates (Warde; 2000:240);

ii. Targeting efficiency akin to conventional finance products while neglecting the ethical concerns of Islamic jurists and economists (El-Gamal:2000);

iii. Directing activity and resources towards the growth of the financial economy rather than the growth of the real economy (Badawi, 1996/1997:20); and

iv. Consistently pursuing profit maximisation and shareholder value at the expense of faith-based ethical principles; which are turned into 'mere mechanisms for a means to an end' (Parker, 2005:2).

Arguably, all of the above points could be said to be entirely consistent with Islamic finance having accepted the central structure of a commercial Bank as a limited liability corporation. As Sheikh Saleh Kamel, founder of one of the oldest and largest Islamic Banks in the Dallah al-Baraka group is reported to have said, "I tell you, truthfully and without pretense, ... that we went beyond choosing the 
"bank" label [in "Islamic Banking"], to the point of adopting its central essence... Consequently, we failed to give our financial institutions any characteristics beyond simple financial intermediation" (El Gamal, 2001). In similar vein, leading Islamic Economist Nejatullah Sidddiqui notes that "The realities of financial markets which prioritize economic incentives rather than religious behavioural norms has forced Islamic finance to become part of the international financial system...the difference has been reduced to technicality, and the value system is no longer mentioned (Siddiqui, 2008).

The result is that today, practically every single Islamic Finance product finds its origins in an economic, risk and cash-flow sense from a commercial equivalent. ${ }^{4}$ Consequentially one of the industry's leading scholars Mufti Taqi Uthmani was driven to write, "Islamic financial institutions have now begun competing to present themselves with all of the same characteristics of the conventional, interest-based marketplace, and to offer new products that march backwards towards interest-based enterprises rather than away... Oftentimes these products are rushed to market using ploys that sound minds reject and bring laughter to enemies (Usmani, 2008)".

Thus the main criticism against mainstream Islamic Finance from both those within and outside is that opposed to the wider socio-ethical remit that Islamic finance should operate in, it has instead been more akin to a "social failure" (Asutay, 2012).

\section{Potential for Reforming IFIs: Reviving the Awqaf}

If the allegation that Islamic Finance has lost its socio-ethical bearings by adopting institutions and norms that arose out of a very different moral fabric is held to be true, then it pays heed to observe which institutions actually best illustrate the opposite, i.e. a dynamic of moral consciousness more synonymous with Islam's ethical imperative. Perhaps the most impressive aspect of Islamdom's prebanking medieval economy was the role of awqaf (plural: waqf); the practice of charitable endowments that were systematised to such a degree that entire nation state economies were able to be supported through their network of philanthropic activities. Historically such privately run endowments provided services throughout the Muslim world in a manner akin to contemporary welfare states; with provision such as food, housing, health and education -all being decentralised and provided at practically zero cost to the State (Çizakca, 1998).

Interestingly, at the time of the dissolution of Ottoman Empire, three-fourths of its land and buildings in some Turkish towns were awqaf. Likewise during the same era, in various Muslim countries, awqaf reached one-third or more of cultivable land. For example, it is historically recorded, at the beginning of $20^{\text {th }}$ 
century in Palestine, that 233 waqf deeds were recorded (owning 890 properties) in contrast to only 92 private ownership deeds (with only 108 properties), thereby clearly showing the focus of the Muslim economy as being an "endowed one" at the time (Ahmed, 2010). The institution of the waqf was not only a pillar of medieval Muslim society, in many cases it served as its very foundation, as a leading Islamic legal text declares, "It is no exaggeration to claim that the waqf, or pious endowment created in perpetuity, has provided the foundation for mисh of what is considered 'Islamic civilization' (Keller, 1994, p. 453)'.

Amongst the various forms of awqaf, the cash waqf, i.e. consisting purely or partially of cash provisioned for a variety of purposes, was historically, in economic terms, the closest precedent to Islamic banks. Cash awqaf often contributed noninterest bearing loans to the public as well as each other through innovative means not entirely dissimilar from modern day Islamic Banks. For example, Cizakca (2004) estimates that about 10 percent of the total eighteenth century population of the city of Bursa, which averaged about 60,000 inhabitants during that period, borrowed from such cash awqaf. Whilst contemporary times have seen this institution cease to play an effective role for a variety of reasons ranging from under-development, colonisation and the establishment of nation states wherein waqf-controlled assets came to be centralised, its revival under Islamic Finance promises to play a central role in the reformation of the industry.

It is thus no surprise to note that scholars such as Cizakca (1992) recommend that Islamic banks be obliged by the government, (or by regulatory authorities such as AAOIFI), to allocate a certain portion (e.g. 5\%) of their investment portfolio per annum to the purchase of waqf certificates, itself forming part of a waqf fund (wherein the certificates would represent a right to the beneficial income although not legal ownership in the underlying assets, as per waqf principles). The allocation and management of such social capital by Islamic banks through investment certificates and the revival of community orientated, decentralised cash based awqaf would allow for mitigation of what has previously been seen as the major hazard/risk pertaining to awqaf, namely the mismanagement of cash by the designated mutawillis (trust managers). Sadeq (2005) and Kamali (2005) argue that successful and professional management of trust-based awqaf community projects would be best orchestrated professionally by Islamic Banks, due to their prior commitment to best practices and standards already in existence with investment funds.

Whilst Islamic banks, being commercial banks, would find it difficult to transform the structure of their balance sheet portfolios, as that would risk compromising deposit or savings usually mandated to be protected by state regulatory authorities; such waqf funds, in a manner akin to investment funds could effectively operate off-balance sheet (See Figure 3 below). This would be particularly feasible, as 
most Islamic banks operate a mandated charity account, thereby allowing them to add seed money to the fund as charity, in addition to managing the funds with a profit generation incentive.

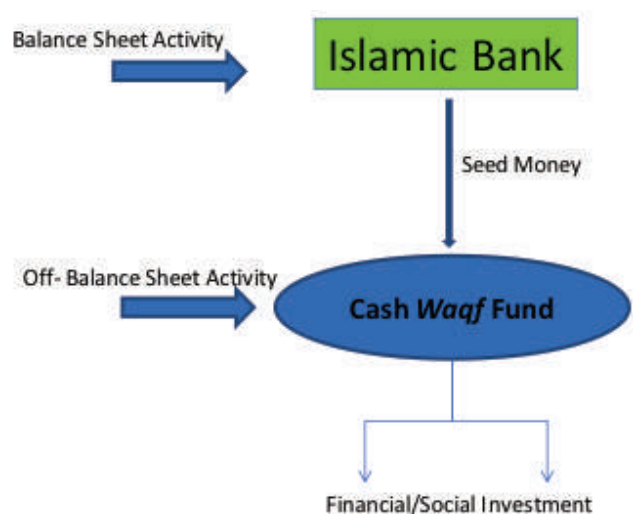

(Source: Author's own)

\section{Figure 3 The Waqf Fund as an Off-Balance Sheet Activity}

The adoption of a model such as that of awqaf which does not place the maximisation of profits as its primary objective, thereby allows for a combination of managerial efficiency and community participation. In such models parent Islamic banks alongside local community and government representation could then be tasked with maintaining the perpetuity of such funds through interim provision of liquidity, if required. Recent developments in the industry indicate that there are institutions paying heed to such opportunities as The Meezan Bank of Pakistan, in their founding of the Ihsan Trust (www.ihsantrust.org), currently manage a cash waqf that provides development microfinance, benevolent loans, and educational grants for financial assistance; all provisioned as the charitable arm of the Bank itself (thereby utilising its seed money in the manner described previously).

All of this indicates that IFIs through setting up cash waqf funds would be ideally placed to provision and support the funding gap that CLT and SOC projects typically face. As any financing would typically involve zero cost of capital and as much of the fund's income could be generated from endowments, the socially rewarding aspects of community projects such as affordable housing could be placed at the forefront alongside expected financial returns. Locally placed projects could also seek to attract direct investment from the community, a process best effected through community based securitisation. 


\section{Securitisation for the Greater Good}

Alongside such a modern revival of awqaf, IFIs could also utilise contemporary financial techniques such as financial securitisation within a community remit. Whilst in an institutional context most Islamic securitisation has effectively sought to replicate the structures of bonds, a fact that can be attributable to point that Islamic Finance assumes the organisational structure, law, regulation and general market framework of commercial banking. It is notable that the adoption of a waqf framework within Islamic banking would allow IFIs to break away from this remit. The potential model of an embedded corporate waqf has begun to bear fruit in places like Malaysia ${ }^{5}$ and could be augmented and better supported by IFIs across the world.

Waqf funds could then be supplemented by IFIs promoting localised community involvement through the selling of waqf certificates. Essentially, these certificates would represent a potential right to income (if such profit/ income is generated) from underlying waqf assets for a limited period, but not an ownership in the underlying assets. A typical structure could be a BOT (BuildOperate-Transfer) concession contract, whereby waqf assets could be built and developed on the premise of future rentals accruing to certificate holders for a limited period, following which the beneficial income from the assets in their entirety would transfer back to the fund. Funds generated thus in return from such potential, limited, circumscribed beneficial ownership could then be used to provision funds for the development and purchase of future community facilities and assets intended to function as endowments. The distinguishing point of these instruments/certificates would be that alongside an investment opportunity, they represent a philanthropic contribution towards local community empowerment. To further the spirit of such charitable endowments, the certificates could be bought in one's own name or in the name of someone deceased.

Whilst a myriad number of uses of such funds collected through a waqf certificate program could be employed, it is possible to foresee social needs such as affordable housing being at the very forefront. In that regard this vehicle would be ideal for providing funding to CLT-SOC projects that could subsequently generate income and returns from the rental of property and land. Pre-development finance could be provisioned by securitising future rentals through the unitisation of potential rental income to certificate holders for a limited duration, after which the rentals would continually support the waqf fund itself. Such a possible structure has been already discussed in the context of proposals by academics such as that of the Community Land Partnership. 


\section{The Community Land Partnership}

Alongside traditional financing (debt/equity), recent times have seen novel ideas with regards to funding CLT-SOC structures through the securitisation of future rental income by the process of unitisation. Chris Cook, a Senior Research Fellow at the University College London (UCL) advocates what he terms a Community Land Partnership (CLP), a structure wherein future rental income in the form of "units" is sold at a discount to provide upfront financing for development costs. It is important to note that the CLP is not an organisation but an innovative use of a UK specific "legal wrapper" model called the Limited Liability Partnership (LLP). Cook argues that the LLP approximates the basic Islamic notion of Partnership of Person, which is, by definition, an approximation of the current concept of limited liability (Swinson, 2004). The LLP model therefore acts as a consensual framework agreement encapsulating various relationships and rights pertaining to shared equity (in this case land and developed property) and achieves them in the context of a CLP as follows:

i. Custodian - who holds the land in perpetuity (operationally the CLT);

ii. Occupier - who occupies the land and buildings;

iii. Investor - who introduces money or "money's worth" in land, property, materials, labor etc. (operationally the Housing Association, Fund, Bank or even private investor) and;

iv. Manager - who develops and manages/maintains the developed land.

According to Cook, rental income from the Occupier can then be "unitised" and sold to Investors as undated credits issued at a discount by the Custodian. In principle, the rentals themselves could then be index-linked (to property values; wages; prices or any combination deemed fit) and Occupiers could themselves become Investors by paying more rental than that due, thereby acquiring units in the pool of future rentals.

Cook's proposed structure holds particular potential for Islamic Finance as the securitisation of future rentals is a dominant structure already employed in the form of ijarah (rental-based) sukuk. Whilst such sukuk currently tend to act as Islamic Capital Market Products and are typically traded in high volume between both Islamic and conventional finance institutions (Ali, 2005), the potential for their adaptation at a more community-focused waqf level is immense. This has recently been potentially demonstrated through a series of innovative large-scale transactions concerning development in Mecca. 


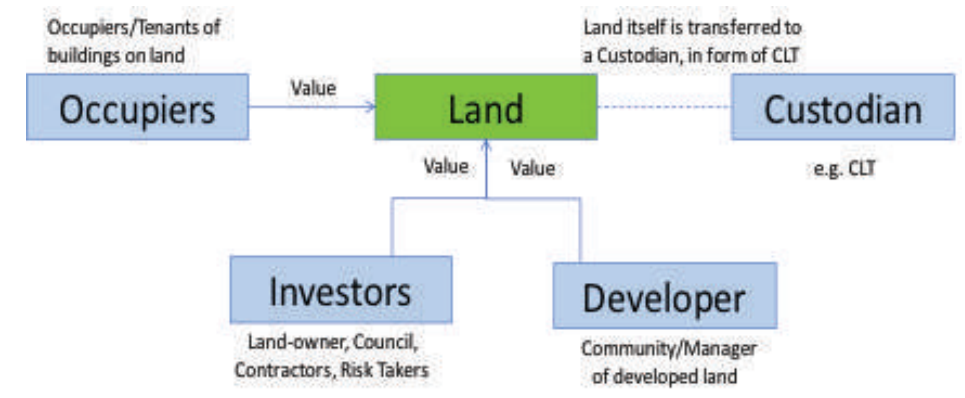

(Source: Author's adaptation of Cook's structure)

\section{Figure 4 Relationship between various parties in a CLP}

\section{Waqf Sukuk: Proof of Concept}

Amongst the most notable waqf sukuk is the construction of the Zam Zam Tower complex, incorporating several five-star chain hotels, a multiplex shopping centre and residential spaces ranging from studios to royal suites, opposite the Grand Mosque in Mecca. With this complex being built upon waqf land as part of the Grand Mosque in Mecca; instead of being sold, the land was leased to a Real Estate development company on a BOT (Build-Operate-Transfer) concession contract for 28 years. Having usufruct rights over a 28 year lease period, the company was then able to raise funds for the project through an innovative waqf sukuk, wherein possessors of the certificates would hold usufruct rights for 24 years (4 years less than the 28 years, thereby covering constructions costs for the building period). Investors in such certificates effectively held a pro-rata share in the sub-lease rental income over 24 years, with the development company making a profit through the rental differentials. The end result thus represented a win-win for all, allowing for a re-transfer of the multi-functional complex back into the possession of the waqf after 28 years. Noticeably, this waqf sukuk was oversubscribed by 135 percent in two years and the development company estimated a rate of return on investment in the region of 26 percent per annum (Ahmed, 2004, p.128).

The remarkable demonstration of 'proof of concept' of the Zam Zam Towers waqf sukuk on such a large industrial scale indicates that the concept could be likewise successfully replicable in local, communitarian projects. The fact that the structure of the waqf sukuk is almost identical to Chris Cook's proposed structure of Community Land Partnership augers well for the development of such waqf sukuk on a local scale by IFIs. 
What this indicates is that the potential upfront capital commitment of IFIs in facilitating such CLP models would be minimal, as it could source such funds through waqf sukuk or waqf certificates. In return as Ahmed (2007) advocates, IFIs could then charge management fees through the offering of a range of waqf management services ranging from custody, estate management, investment management and general advisory services (Ahmed, 2007 and 2011). The result would be a potentially changed dynamic with regards to the interaction between IFIs and social finance, one that resonates with the founding principles originally advocated by Islamic finance's early proponents.

\section{More than just an Alternative Mode of Finance}

Islamic Finance was not intended simply to replicate modern mainstream financial norms with an Islamic label. Similarly, pioneers of alternative financial models such as CLTs and SOCs did not see their proposed solutions as being stand-alone entities but rather facets of an entirely different financial movement. Early proponents of CLTs such as Robert Swann (Swann, 1989) envisaged community orientated, decentralised, democratic economics and saw CLTs as advocating a vital set of means to encourage local, bioregional economies. In this manner he and others of similar ilk were inspired by alternative economists such as E.F. Schumacher who argued in his book Small is Beautiful: Economics as if people mattered that from a truly economic point of view the most rational way to produce is "from local resources, for local needs" (Schumacher, 1989). Socio-economic activists such as Swann, Schumacher and others foresaw such movements as being in opposition to modern day market economics, which effectively prioritised "Profit over People" (Chomsky, 1999). It was in response to this imperative that they advocated for ownership of land, natural resources, industry and the determination of conditions for receiving credit to be decentralised, such that they could all be more responsive to local and regional needs and conditions. Within this framework, CLTs and SOCs were intended to help facilitate the decentralisation of the control of land and financing in order to better serve local people in a more equitable way. All of this stated agenda could be said to be akin in spirit to the nature of community orientated, decentralised, endowed economies that characterised the Muslim world during its golden period in the middle ages.

In contrast, today's modern day IFIs with their debt-based, impersonal "financing", best illustrated in the realm of property through each of the dominant forms of Islamic home finance (be they Murabaha, Ijara Muntahia Bitamleek or Diminishing Musharaka) all imitate the cash-flow and economic effects of a modern day interest-based mortgage. When we reflect upon the fact that property 
is the dominant asset by which most banks produce credit or money, as the Chairman of the Financial Services Authority (UK) Lord Adair Turner states, "over 75\% of banks' lending (and hence money creation) goes into property" (The Independent, 2012), IFIs operating within the parameters of banking are to be expected to follow suit. If the current practice of reductive focus on transactional validity within Islamic Finance has arguably unwittingly co-opted its institutions into a debt-based, interest-inspired logic, it is no surprise that Islamic home financing currently seeks to mimic interest-debt financing through debatable contractual means. The result, as Maulana Akram Nadwi notes is that, "the instruments and transaction contracts that are billed under Islamic finance ...build or propose legal solutions on the pattern of terminology and contracts... without any regard for whether the general outcome to which these contracts contribute is even tolerable, let alone desirable (Nadwi, 2013)".

This paper states that there is a way to change this. It concludes that IFIs can rectify this malpractice of lack of vision by seeking synergy with initiatives that focus on counteracting the effects of interest such as CLTs and SOCs, rather than normalising those that have arisen out of it, such as Banks and debt based mortgages. If contemporary bank lending for mortgages is not only the primary cause for property price inflation, but also brings about the effective privatisation of land, real estate and other assets in the hands of an increasingly receding privileged financial elite, thereby favoring the financial economy in preference to the real one - is it not time that Islamic Finance thought outside of the "banking" box? Rhetoric aside, Islamic Finance scholars and practitioners owe it to their profession and training to employ a wider lens when engaging in analysis of current products detailing the home finance space. As this paper highlights, a detailed look at the revival of community orientated cash awqaf alongside the use of similarly geared waqf sukuk could provide financial support for CLT and SOC inspired projects. Movement in the right direction allows for the opportunity of failure to become success, whereas that in the wrong direction only amounts to successful delusion; it's time IFIs paid heed to the perennial question:

\section{"So where then are you headed?"}

[Qur'an: 81:26]

\section{Policy Recommendations}

- Islamic Banks in support with Central Banks can establish cash waqf funds as off-balance sheet investment funds. ${ }^{6}$

- These cash waqf funds can have their own independent governance structures overseen by Central Bank authority. Their Boards should consist 
of local community representatives, thereby establishing a separation between the parent commercial bank entity and the waqf fund; akin to Glass-Steagal Legislation.

- Ideally the cash waqf should establish sister relationships with cash awqaf of other Islamic Banks, allowing for mutual indemnification along takaful/ re-takaful lines.

- The priority of investment activities of any cash waqf should be socially orientated, of local jurisdiction and benefit such as affordable housing.

- Investment opportunities into affordable housing and other social ventures could also involves solicitation of funds from public through waqf sukuk certificates.

- These Certificates would represent pro-rate share of income/revenue to be derived from projects under the cash waqf funds such as affordable housing.

- An example project would be a Community Land Partnership (see paper), which would allow for an efficient use of securitising future rental income to fund a BOT (Build-Operate-Transfer) model that eventually transfers the housing infrastructure and land into the corpus of the fund.

- Eventually a nationwide Community Land Trust/cash waqf fund can be developed by government authorities, to provide interim financial support to the privately run cash awqaf, thus assisting their funds perpetuity along Waqf lines. ${ }^{7}$

\section{References}

Ahmed, H. (2004). 'Role of Zakah and Awqaf in Poverty Alleviation'. Occasional Paper No. 8. Jeddah KSA.: IRTI. Available from: http://www.irtipms.org/ PubText/201.pdf [accessed 06 May, 2014].

Ahmed, H. (2007). Waqf-Based Microfinance: Realizing the Social Role of Islamic Finance. Paper written for the International Seminar on "Integrating Awqaf in the Islamic Financial Sector", Singapore. Available from: http://imfn.org/images/ Litrature/Waqf-Based\%20Microfinance $\% 20$ Realizing\%20The $\% 20$ Social $\% 20$ Role\%20Of\%20Islamic.pdf [accessed on 06 May, 2014]

Ahmed, H. (2011). Waqf as a Sustainable Social Enterprise: Organisational Architecture and Prospects. Global Islamic Finance 32-39.

Ahmad, T. (2010). Integrating the Awqaf into the Islamic Financial Sector. Unpublished.AHURI, Australian Housing and Urban Research Institute, (2011). Gentrification and displacement: the household impacts of neighbourhood change. AHURI Final Report No. 160.

Armor, J. Hansman, H. and Kraakman, K. (2009), The Essential Elements of Corporate Law, University of Oxford, Legal Studies Research Paper No. 20/2009. 
Asutay, M. (2004). MFP 211 Research Methodology in Social Sciences; Lecture 5: Research Methodology. Markfield U.K: M.I.H.E.

Asutay, M. (2007) "Conceptualisation of the Second-best Solution in Overcoming the Social Failure of Islamic Banking and Finance: Examining the Overpowering of Homo Islamicus by Homo Economicus," IIUM Journal of Economics and Management 15, no. 2, pp. 167-95.

Asutay, M. (2008), Islamic Banking and Finance: Social Failure. New Horizon (169), pp. 1-3.

Asutay, M. (2012), Conceptualising and Locating the Social Failure of Islamic Finance: Aspirations of Islamic Moral Economy vs. the Realities of Islamic Finance. Asian and African Area Studies 11(2), pp. 93-113.

Ali, Salman, Syed (2005) "Islamic Capital Market Products: Developments and Challenges" Section 3.2, Jeddah: Islamic Research and Training Institute, Islamic Development Bank.

Barker, K. (2004), Delivering Stability: Securing our Future Housing Needs: Final Report-Recommendations, Review of Housing Supply, London, HM Treasury.

Bank of England Speech, (2007). Paul Tucker, Executive Director, Monetary Policy Committee, Bank of England. Available at: http://www.bankofengland.co.uk/ publications/Documents/speeches/2007/speech331.pdf [accessed 26 March, 2014]

Bakan, J. (2005), The Corporation: The Pathological Pursuit of Profit and Power, Free Press.

Baqir al-Sadr, M. (1968; 2:648). Iqtisaduna, Beirut, Dar al-Fikr.

Business Wire News database, (2009). Two top economists agree 2009 worst financial crisis since great depression; risks increase if right steps are not taken. Available at: http://www.reuters.com/article/2009/02/27/idUS193520+27-Feb2009+BW20090227 [accessed 04 February, 2014]

Brown, E.H. (2008), Web of Debt: The Shocking Truth About Our Money System and How We Can Break Free, Third Millennium Press.

Brown, E. (2012). It's the Interest! Why Bankers Rule the World. See: http://truthout.org/news/item/12605-its-the-interest-stupid-why-bankers-rule-the-world> [accessed 26 March, 2014]

Bryman, A. and Bell, E. (2007), Business Research Methods, 2nd ed., Oxford University Press.

Carswell, A. ed. (2012), "Shared Equity Homeownership" The Encyclopedia of Housing (Second Edition), (Los Angeles, CA: Sage Publications, pp.666-670).

Chapra, U. (1970: 54). The Economic System of Islam: A Discussion of its Goal and Nature. London: Islamic Cultural Centre.

Chapra, U. (2000). The Future of Economics- An Islamic Perspective. Markfield, U.K: The Islamic Foundation.

Chomsky, N. (1999). Profit Over People: Neoliberalism and Global Order. Seven Stories Press.

Çizakca, M. (1998). Awqaf in History and its Implications for Modern Islamic Economies, Islamic Economic Studies, Vol. 6, No. 1, November 1998. Available at: http://waqaf.org.my/wp/wp-content/uploads/2013/11/Awqaf-in-History-andits-Implications-for-Modern-Islamic-Economies-Murat-Cizakca.pdf [accessed 03 May 2014] 
Çizakca, M. (2002). "Latest Developments in the Western Non-Profit Sector and Implications for Islamic Waqf”, in M. Iqbal (Ed), Islamic Economic Institutions and the Elimination of Poverty. (pp. 263-297). Markfield, U.K: The Islamic Foundation.

Çizakca, M. (2004). Ottoman Cash Waqfs Revisited: The Case of Bursa 15551823. Manchester: Foundation for Science Technology and Civilisation (FSTC Limited).

CLT Legal Toolkit, n.d. The National CLT Network UK: CLT Legal Toolkit. Available at: http://www.communitylandtrusts.org.uk/resources/toolkits/Legal-Toolkit [accessed 28 April, 2014]

Cohen, L., Manion, L. \& Morrison, K. (2000). Research Methods in Education, 5th Edition, London: Routledge Falmer.

Community Finance Solutions, (2009). Lessons from the first 150 Homes: Evaluation of the National Community Land Trust Demonstration Programme 20062008. Available from: http://www.communitylandtrusts.org.uk/upload/public/ Publications/150homes.pdf [accessed 04 May, 2014]

Council of Mortgage Lenders, (n.d.) Growth in buy-to-let faster than market as whole. Available at: http://www.cml.org.uk/cml/media/press/1112 [accessed 23rd February, 2014]

Dar, H. (2002). Growing Mainstream Relevance of Islamic Finance. A Critical Review of Recent Literature. Review of Islamic Economics, 11, pp 63-72

Davis, J.E. and Demetrowitz, A. (2003), Permanently Affordable Homeownership: Does the Community Land Trust Deliver on Its Promises? A Performance Evaluation of the CLT Model Using Resale Data from the Burlington Community Land Trust. Burlington Community Land Trust. Available from: http:/www. community-wealth.org/sites/clone.community-wealth.org/files/downloads/ report-davis.pdf [accessed 11 March, 2014]

Davis, J.E. (2006), Shared Equity Homeownership: The Changing Landscape of Resale-Restricted, Owner-Occupied Housing. National Housing Institute. Available from: http://www.nhi.org/pdf/SharedEquityHome.pdf [accessed 02 March, 2014]

Davis, J.E. (2008). "Homes that Last: The Case for Counter-Cyclical Stewardship". Shelterforce. Available from: http://shelterforce.org/article/homes that last/ [accessed 04 May, 2014]

Davis, J.E. ed. (2010), The Community Land Trust Reader. Lincoln Institute of Land Policy.

Deborah, O. (2012). Guardian Online: Yes, banking's a mess, but be part of the solution. Move your money! See: http:/www.guardian.co.uk/commentisfree/2012/jul/13/ deborah-orr-better-banks-move-money [accessed 26 March, 2014]

Delorenzo, Y.T. (1999), Murabaha, Sales of Trust, and the Money-value of Time, Harvard University Forum on Islamic Finance: Islamic Finance into the 21st Century. Cambridge, Massachusetts. Center for Middle Eastern Studies, Harvard University. 1999. pp. 145-150.

Diwany, T.E. (2003), The Problem With Interest, Kreatoc Ltd.

Dyson, B. (2011). Guardian Online: Money has been Privatised by Stealth. See: http://www.guardian.co.uk/commentisfree/2011/nov/15/money-privatisedstealth $>$ [accessed 26 March, 2014] 
East London Community Land Trust (ELCLT), n.d. East London Community Land Trust: A Case Study, Community Finance Solutions. Available at: http:// www.communitylandtrusts.org.uk/upload/public/Case $\% 20$ Studies/East $\% 20$ London\%20Community\%20Land\%20Trust.pdf [accessed 01 May, 2014].

Economist, "Sell em' dear", Available from: http://www.economist.com/blogs/ buttonwood/2009/07/sell_em_dear. [accessed 23rd February, 2014].

Ernst and Young, World Islamic Bänking Competitiveness Report 2013-14. Available at: http://emergingmarkets.ey.com/wp-content/uploads/downloads/2013/12/ World-Islamic-Banking-Competitiveness-Report-2013-14.pdf [accessed 06 March, 2014].

Eisenstein, C. (2007), The Ascent of Humanity, Panenthea Productions.

Eisenstein, C. (2011), Sacred Economics: Money, Gift, and Society in the Age of Transition, Evolver Editions.

El-Gamal, M. (2000), The Economics of 21st Century Islamic Jurisprudence. Available from: http://www.ruf.rice.edu/ elgamal/files/jurists.pdf [accessed 06 March 2014].

El-Gamal, M. (2001), "Interest” and the Paradox of Contemporary Islamic Law and Finance. Available at: http://www.ruf.rice.edu/ elgamal/files/interest.pdf [accessed 06 March, 2014].

Greater London Authority (GLA), (2004). Community Land Trusts \& Mutual Housing Models. Available at: http://www.andywightman.com/docs/community_land trusts_models.pdf [accessed 01 May, 2014].

Hasan, Z. (2005a). "Islamic Banking at the Cross Roads: Theory Versus Practice”, in Iqbal, M. and Hassan, Z. (2005b). "Evaluation of Islamic Banking Performance, On the Current Useof Econometric Models”, in Islamic Economics and Banking in the 21st Century, paper presented at the 6th International Conference on Islamic Economics and Finance, Jakarta, Indonesia, November 21-24, 2005, (1), pp. 229-248.

Hasan, Z. (2004). "Measuring the Efficiency of Islamic Banks; Criteria, Methods and Social Priorities”. Review of Islamic Economics 8 (2), pp. 5-30.

Housing Strategy Statistical Appendix Data, (2010). Communities and Local Government, UK. Available at: https:/www.gov.uk/government/uploads/system/ uploads/attachment_data/file/6910/2039199.pdf

Hussey, J. and R. Hussey, (1997) Business Research: A Practical Guide for Undergraduate and Postgraduate Students. London, Macmillan.

Iqbal, M \& Molyneux, P. (2004). Thirty years of Islamic Banking; History, Performance and Prospects. U.K.: Palgrave Macmillan.

Iqbal, M \& Wilson, R. (2006). Islamic Perspectives on Wealth Creation. Edinburgh U.K.: Edinburgh University Press.

Kahf, M. (1995). Waqf: The Oxford Encyclopedia of the Modern Islamic World. New York: Oxford University Press.

Kahf, M. (2004). Shariah and Historical Aspects of Zakah and Awqaf. Jeddah:

Paper prepared for Islamic Research and Training Institute, Islamic Development Bank.

Keller, N. (1994). The Reliance of the Traveller. Amana Publications.

Kennedy, M. (2012), Occupy Money: Creating an Economy Where Everybody Wins, New Society Publishers. 
Korten. D.C (2001), When Corporations Rule the World, Berrett-Koehler Publishers Korten. D.C (2010), Agenda for a New Economy: From Phantom Wealth to Real Wealth, Berrett-Koehler Publishers

Locke, L.F., Silverman, S.J. \& Spirduso, W.W. (1998). Reading and Understanding Research. Thousand Oaks CA: Sage Publications.

Mawdudi S. A. A. (1969:436). Ma'shiyat-e-Islam (Urdu). Lahore: Islamic Publications.

National Statistics, (2010). Housing Statistical Release: Household Projections, 2008 to 2033, England. Available from: https://www.gov.uk/government/ uploads/system/uploads/attachment_data/file/6395/1780763.pdf [accessed 04 May, 2014].

New Economics Foundation (NEF) (2003), Common Ground - for Mutual Home Ownership: Community land trusts and shared-equity co-operatives to secure permanently affordable homes for key workers, The New Economics Foundation. Available from: http://www.neweconomics.org/sites/neweconomics.org/files/ CommonGround.pdf [accessed 18 February 2014].

Obaidullah, M. (2014), Engineering a Waqffor Adahi: Awqaf New Zealand. Available from: http://sadaqa.in/2014/04/15/engineering-a-waqf-for-adahi-awqaf-newzealand/ [accessed 05 May, 2014].

Parker, M. (1996 October; 10:2). “Beware of the Costly Corner-Cutter”. Islamic Banker.

Parker, M. (2004 April; 2:99). “In Search of Islamic Banking's Corporate Man”. Islamic Banker.

Parker, M. (2005, March/April). A Tale of Two Corporate Identities. Islamic Banker 10/11, p. 6-7.

Paterson, B \& Dayson, K. (2011). Proof of Concept: Community Land Trusts, Community Finance Solutions, University of Salford Publication. Available from: http://www.communitylandtrusts.org.uk/upload/public/Publications/ Proof $\% 20$ of $\% 20$ Concept $\% 20$ Final.pdf [accessed 01 May, 2014].

Positive Money, n.d. The Money Multiplier and other Myths about Banking. Available from: https://www.positivemoney.org/how-money-works/advanced/the-moneymultiplier-and-other-myths-about-banking/ [accessed 28 April, 2014].

Rowbotham, M. (1998), The Grip of Death: A Study of Modern Money, Debt Slavery and Destructive Economics, The Cromwell Press.

Ryan-Collins. J, Werner. R and Greenham. T (2011), Where does Money come from? A guide to the UK Monetary and Banking System, NEF (the new economics foundation).

Salomon, L.M. \& Helmut, K.A. (1997), Defining the Non-profit Sector, A CrossNational analysis. Manchester and New York: Manchester University Press.

Schumacher, E.F. (1989) Small is Beautiful: Economics as If People Mattered. New York: Harper Perennial.

Sen, A. (1987), On Ethics and Economics. Oxford: Basil Blackwell.

Shelter: The Housing and Homelessness Charity (2013), Food for Thought: Applying House Price Inflation to Grocery Prices, Shelter Policy Library. Available from: http://www.shelter.org.uk [accessed 18 February, 2014].

Speth, J.G. (2008). The Bridge at the Edge of the World: Capitalism, the Environment, and Crossing from Crisis to Sustainability, $1^{\text {st }}$ ed. Yale University Press. 
Siddiqi, M.N. (2000). “Islamic Banks: Concept, Precepts and Prospects”. Review of Islamic Economics, 9 (1), pp. 21-35.

Siddiqi, M. N. (2008). “Obstacles to Research in Islamic Economics”, Proceedings of The Seventh International Conference on Islamic Economics, Islamic Economics Research Center, KAAU, Jeddah, April 1-3, 2008. Available from: http://islamiccenter.kaau.edu.sa/7iecon/English/English\%20Contents.htm [accessed 5 May, 2014].

Swann, R; Benello, C. and Turnbull, S. (1989). Building Sustainable Communities: Tools and Concepts for Self-Reliant Economic Change. New York City, NY: Bootstrap Press.

Swinson, A. (2004). "On the trail of a new animal”, Regeneration and Renewal Magazine, pp. 20-21.

Troidos Bank, Business Banking FAQs: Do you lend to Community Land Trusts (CLTs)? [online] Available from: http://www.triodos.co.uk/en/business/service/ faq/?faqId=138281 [accessed 04 March 2014].

The Independent Blog, "Why exactly is it expensive for us to buy a home?" Available at:http://blogs.independent.co.uk/2012/08/28/why-exactly-are-homes-soexpensive/ [accessed 23 February, 2014].

Parker, M. (2005, March/April). "A Tale of Two Corporate Identities”. Islamic Banker 10/11, pp. 6-7.

UN-Habitat (2010). World Population Prospects, The 2010 Revision, New York: United Nations.

Usmani, T. (2008). Sukuk and their Contemporary Applications. Available from: http://www.muftitaqiusmani.com/images/stories/downloads/pdf/sukuk.pdf [accessed 06 May 2014].

Warde, I. (2000). Islamic Finance in the Global Economy. Edinburgh: Edinburgh University Press.

Wilson, R. (eds.), Islamic Perspectives on Wealth Creation. Edinburgh: Edinburgh University Press, pp. 11-25.

Wilson, R. (1997). “Islamic Finance and Ethical Investment”. International Journal of Social Economics, 11(1), pp. 51-62.

Zarqa, M.A. (1994). "Financing and Investment in Awqaf Projects: A Non-Technical Introduction”. Islamic Economic Studies, 1 (2), pp. 55-62.

Zaman, A. (2008), Islamic Economics: A Survey of the Literature. Unpublished.

\section{Notes}

* The Author is a Chartered Sharia Auditor and Advisor formally certified by the Accounting and Auditing Organization for Islamic Financial Institutions, currently working for a GCC based Islamic Bank as a Manager in charge for Sharia Consultation and Documentation. Having received formal training in Islamic wills and inheritance tax and investment planning in the UK, he is also qualified as a UK Chartered Independent Financial Advisor. Email: yusuf.jha@ gmail.com.

1. Whilst such controls may raise objections with free market principles within both the conventional and Islamic finance space, it is important to note that mainstream Islamic finance like its conventional counterpart regularly employs 
resale price cap mechanisms in the context of sale, lease and buy-back transactions regularly employed for financing and sukuk, in a manner akin to a financial lease. If Islamic finance scholars can accept such modus operandi to effectively mimic the financing mechanics of an interest based loan, it is expected that such controls to promote a greater social good like affordable housing would attract similar if not more support.

2. See website: http://www.glenkerry.org.uk/

3. The Community Land Trust Fund is an approximately $£ 2 \mathrm{~m}$ fund managed by the Charities Aid Foundation set up to assist the development of CLTs throughout the UK. See: http://www.cltfund.org.uk/about [accessed 05 March, 2014].

4. This could be posited as the real reason why Organizational Tawwarruq though effectively deemed non-Shari'a compliant by AAOIFI continues to be in widespread use across Islamic Financial Institutions; i.e. they have to mimic an interest based loan for short-term liquidity requirements due to institutional expectations (Khan, 2009). Similar arguments and 'expectations' could be extended to a whole plethora of Islamic Finance products.

5. See for example the Waqaf An-Nur Corporation Berhad (WANCorp), essentially being a Corporate Waqf run and managed by the Johor Corporation (JCorp), itself a State Investment Corporation in the state of Johor, Malaysia. Amongst the flagship initiatives of the corporate Waqf are: owning and managing a chain of 17 clinics and a full-fledged hospital, providing start-up capital for Microenterprises, Disaster relief and the management of a chain of seven mosques catering to over 15,000 worshippers (Obaidullah, 2014).

6. See Ihsan Trust of Meezan Bank, Pakistan, as a potential model: http://www. ihsantrust.org/

7. See Community Land Trust Fund supporting CLTs in England and Wales: http:// www.cltfund.org.uk/ 